\title{
PENGARUH PENGUNGKAPAN TATA KELOLA PERUSAHAAN TERHADAP AKURASI HARGA SAHAM PADA PERUSAHAAN YANG TERDAFTAR DI BURSA EFEK INDONESIA TAHUN 2013-2017
}

\author{
Budi Harsono dan Edwin Saputra* \\ *Jurusan Akuntansi, Fakultas Ekonomi \\ Universitas Internasional Batam \\ Email: edwinyap.LAE96@yahoo.com
}

\begin{abstract}
This study was conducted to analyze the effect of corporate governance disclosure to Share Price Accuracy. The variables of corporate governance disclosure in this study are divided into two namely Mandatory Corporate Governance Disclosure and Voluntary Corporate Governance Disclosure.

The data obtained in this research is secondary data. The Secondary data used are financial statement data and company annual report data. Secondary data can be downloaded from Indonesian stock exchanges official website via www.idx.co.id. The number of companies used as research samples are 393 companies. The study period began from 2013 to 2017. The data obtained were as many as 1965 data.

The conclusion of this study prove that both of the independent variables have a significant effect to Share Price Accuracy.Mandatory Corporate Governance Disclosure has a significant positive effect to the Share Price Accuracy partially.Voluntary Corporate Governance disclosure also has significant effect to the Share Price Accuracy partially.
\end{abstract}

Keywords: Mandatory Corporate Governance Disclosure, Voluntary Corporate Governance Disclosure, Share Price Accuracy

\section{INTRODUCTION}

Saham merupakan sebuah bukti tanda kepemilikan pemegang saham dalam suatu perusahaan. Seperti yang diketahui, tanda kepemilikan Saham berwujudkan selembar kertas berharga yang diterbitkan oleh perusahaan. Sejak masuk ke era digital, wujud saham tidak berupa kertas, melainkan berupa akun atas nama pelaku saham. Saham dapat dikategorikan sebagai instrumen investasi yang menarik karena saham dapat membawa tingkat pengembalian yang tinggi tetapi tingkat risiko juga tinggi (Paramitasari, 2014).

Sebelum melakukan investasi saham di suatu perusahaan, para pelaku pasar berusaha untuk memperoleh informasi yang berhubungan dengan perusahaan. Setelah berhasil memperoleh informasi tersebut, para pelaku pasar bisa membuat keputusan untuk investasi yang baik dan benar.Suatu informasi dianggap informatif jika informasi tersebut dapat mempengaruhi keputusan investor untuk melakukan investasi saham (Zamzany et al., 2018).

Tujuan salah satu pelaku pasar yakni investor untuk menginvestasi saham adalah untuk memperoleh bagi hasil untung berupa dividen atau capital gain. Namun investasi merupakan suatu hal yang tidak dapat dijamin keuntungannya karena pergerakan harga saham di setiap perusahaan fluktuasinya sangat tidak stabil. Fluktuasi harga saham perusahaan atau indeks dapat dipengaruhi oleh macam-macam faktor seperti pengungkapan informasi, faktor internal, faktor eksternal perusahaan, dan lain sebagainya. Faktor-faktor fluktuasi harga 
saham merupakan risiko dalam investasi harga saham.

Dalam menentukan prediksi harga saham jangka pendek seperti harga saham harian memerlukan metode, model dan pendekatan yang teruji akurasinya. Semakin teruji suatu metode akurasi harga saham, maka metode tersebut akan semakin diminati oleh para pelaku pasar seperti investor, broker, analis. Bagi para pelaku pasar, hal yang paling penting yaitu mendapatkan informasi yang dapat mempengaruhi perubahan harga saham sehingga dapat menghasilkan keuntungan dalam waktu yang singkat (Haeberle, 2015).

Harga saham yang akurat dapat memberikan beberapa manfaat sosial seperti mencerminkan arus kas masa depan, meningkatkan nilai perusahaan, sebaliknya jika harga saham yang tidak akurat dapat menyebabkan keyakinan para pelaku pasar. Jika pasar saham yang likuiditasnya kurang memadai, akan menyebabkan proses likuiditas semakin sulit dan mahal (Haeberle, 2015).

Kinerja ekonomi indonesia dicerminkan melalui Indeks Harga Saham Gabungan (IHSG). Keadaan faktor makroekonomi sebagai salah satu faktor eksternal dapat berpengaruh terhadap kinerja, nilai dan harga saham perusahaan. Faktor makroekonomi merupakan salah satu pengukuran investor untuk mengambil keputusan investasi berdasarkan keadaan pasar (Morck et al., 2000).

Salah satu Contoh dari faktor makroekonomi adalah inflasi. Tingkat Inflasi yang tinggi dapat menyebabkan harga perolehan bahan baku, upah serta biaya operasional ikut meningkat. Naiknya harga bahan baku dapat menurunkan daya beli masyarakat maupun perusahaan. Seiring dengan peningkatan biaya dapat menyebabkan laba perusahaan menurun. Laba perusahaan menurun menyebabkan jumlah pembayaran dividen kepada investor menjadi sedikit dan bahkan tidak ada pembayaran dividen jika perusahaan mengalami kerugian atau defisit (Astuti et al, 2016).

Laba atau ruginya perusahaan menjadi pertimbangan investor untuk memutuskan penarikan dana investasi sehingga alokasi modal perusahaan menjadi berkurang. Alokasi modal perusahaan yang tidak efisien dapat menyebabkan harga saham menurun sehingga harga saham menjadi tidak akurat (Kahan, 1992)

Berdasarkan latar belakang yang telah dirumuskan diatas, karya ilmiah ini menggunakan perusahaan yang terdapat di Bursa Efek Indonesia mulai dari tahun 2013-2017. Judul dari karya ilmiah ini adalah "Pengaruh Pengungkapan Tata Kelola Perusahaan Terhadap Akurasi Harga Saham pada perusahaan yang terdaftar di Bursa Efek Indonesia Tahun 2013-2017'.

\section{LITERATURE REVIEW AND HYPOTHESIS DEVELOPMENT}

Menurut Odhiambo(2000), Harga saham yang akurat dapat di artikan sebagai harga yang tidak mengurangi atau melebihi posisi pasar. Biasanya harga saham yang akurat tergantung jumlah dan kualitas informasi yang diperoleh oleh pelaku pasar. Contoh pelaku pasar yang dimaksud disini adalah bank, perusahaan sekuritas, dan lain sebagainya. Konsep dari akurasi harga saham adalah seberapa baik harga saham sebagai prediktor arus kas masa depan (seperti dividen dan distribusi lainnya) yang akan diterima oleh pemegang saham dari perusahan penerbit saham tersebut (Fox et al, 2003).

Harga pasar saham dapat mencerminkan nilai fundamental dengan tingkat yang berbeda-beda. Ketika harga tersebut mendekati nilai fundamental, maka harga tersebut dikatakan memiliki akurasi yang tinggi. Namun sebaliknya jika harga tersebut jauh dari nilai fundamental maka, harga tersebut dikatakan memiliki akurasi yang rendah (Haeberle, 2015). 
Harga saham yang akurat dapat meningkatkan jumlah nilai tambah perusahaan karena perusahaan menggunakan sumber daya manusia seperti karyawan untuk memproduksi barang dan jasa. Dalam dunia ekonomi yang penuh kompetitif ini, peningkatan nilai tambahan perusahaan akan meningkatkan arus kas perusahaan. Akurasi harga saham dan pengungkapan yang baik dapat menciptakan manfaat sosial dan mengurangi biaya agensi (Jensen \& Meckling, 1976).

Dengan berkurangnya biaya agensi dan tambahan dorongan manfaat sosial, maka kegiatan operasional perusahaan akan semakin meningkat sehingga kinerja ekonomi juga ikut meningkat secara keseluruhan. Harga saham yang akurat dapat berfungsi sebagai sarana untuk memastikan keputusan investasi yang lebih baik serta meningkatkan tata kelola perusahaan (ElKelish \& Hassan, 2015).

MenurutFox et al, (2003) Penentuanutama dari akurasi harga saham terdiri dari :

1. Lamanya waktu sebelum distribusi

2. Insentif ekonomi dan hukum untuk membagi, mengumpul, dan berdagang informasi dan interaksi mereka

Penelitian pengungkapan tata kelola perusahaan wajib terhadap Share Price Accuracy masih sangat terbatas. Penelitian terdahulu oleh Romano (1998) dan Macey (1993) menunjukan bahwa pengungkapan wajib tidak dapat meningkatkan share price accuracy karena pergerakan harga saham juga dipengaruhi oleh informasi yang beredar di pasar saham seperti pihak analisis industri, media massa.

Namun Penelitian berikutnya

menunjukan Mandatory Corporate

Governance Disclosure berpengaruh signifikan positif terhadap Share Price Accuracy. Pengungkapan wajib dapat meningkatkan share price accuracy secara efektif. Karena adanya pengungkapan wajib menyebabkan perusahaan untuk mengungkapkan informasi. Informasi tersebut dapat menyebabkan pergerakan harga saham suatu perusahaan naik maupun turun. Pengungkapan wajib merupakan upaya yang baik untuk memerangi modal karena investor dapat mengakses aktivitas apa saja yang telah yang terjadi di dalam perusahaan secara permanen (Fox et al., 2003).

Keberadaaan pengungkapan sukarela dapat mengurangi kegelapan yang membuat transparansi perusahaan meningkat. Efek dari Transparansi terhadap harga saham kemungkinan akan sangat jelas ketika pengungkapannya tidak jelas. Dalam arti, bahwa pasar telah menerima sejumlah informasi yang relevan untuk arus kas masa depan. Meningkatnya transparansi dapat membuat investor semakin yakin untuk membuat keputusan investasi yang benar (Farvaque, et al, 2011).

Penelitian oleh ElKelish \& Hassan, (2015) memberikan bukti bahwa Voluntary Corporate Governance Disclosure berpengaruh signifikan positif terhadap Akurasi Harga Saham. Karena pelaksanaan praktek pengungkapan sukarela terhadap perusahaan memberikan informasi kepada pemegang dan pemilik saham atas tata kelola perusahaan atau entitas yang memadai. Serta membuat pemegang saham mengerti atas keputusan dan perencanaan yang dibuat oleh perusahaan.

Berdasarkan pembahasan pada penelitian terdahulu, maka hipotesis yang dapat diambil adalah :

H1: Mandatory Corporate Governance Disclosure berpengaruh signifikan terhadap Akurasi Harga Saham

H2: Voluntary Corporate Governance Disclosure berpengaruh signifikan terhadap Akurasi Harga Saham

\section{RESEARCH METHODOLOGY}

Penelitian yang digunakan dalam penelitian ini yaitu penelitian kuantitatif. Penelitian kuantitatf pada penelitian ini memiliki tujuan untuk menguji pengaruh pengungkapan tata kelola perusahaan terhadap akurasi harga saham perusahaan 
yang terdaftar di Bursa Efek. Data yang digunakan untuk melaksanakan penelitian ini yaitu data laporan tahunan dan laporan keuangan. Data laporan keuangan dan laporan tahunan dapat diperoleh melalui situs resmi bursa efek indonesia yaitu www.idx.co.id.

\section{Variabel Dependen}

Variabel dependen pada penelitian ini yaitu Akurasi Harga Saham. Perhitungan atau rumus untuk Share Price Accuracy diperoleh dari varians pengembalian saham pasar dibagi dengan varians pengembalian saham perusahaan. Perhitungan rumus Share Price Accuracy dapat ditulis dengan rumus berikut :

Market return yang digunakan adalah return IHSG dari tahun periode

\section{Variabel Independen}

Didalam variable independen terdapat dua variabel independen yaitu Mandatory Corporate Governance Disclosure (MCDGI) dan Voluntary Corporate Governance Disclosure (VCDGI).

\section{Mandatory Corporate Governance Disclosure (MCDGI)}

Mandatory Corporate Governance Disclosure dapat diukur dengan jumlah indeks pengungkapan informasi tata kelola perusahaan secara wajib dibagi dengan total indeks pengungkapan informasi tata kelola perusahaan secara wajib. Nilai pengungkapan meunjukan 1 apabila perusahaan ada mengungkapan informasi pada periode itu tersebut, jika tidak ada maka nilai pengungkapan adalah 0 . Adapun total Mandatory Corporate Governance Disclosure Index yang digunakan dalam penelitian ini sebanyak 13 perusahaan. Mandatory Corporate Governance Disclosure Index terdiri dari informasi berikut ini :

1. Saham Treasuri;

2. Transaksi pihak berelasi;

3. Anggota dewan direksi;

4. Struktur organisasi;
2013 sampai dengan tahun periode 2017. Sedangkan company return yang diperoleh dalam penelitian ini adalah harga saham perusahaan publikpada saat penutupan yang telah terdaftar di Bursa Efek Indonesia dari tahun periode 2013 sampai dengan tahun periode 2017. Maka, perhitungan rumus Market return dan Company return adalah selisih dari harga saham atau indeks periode $\mathrm{t}$ dan tahun periode sebelumnya dibagi dengan harga indeks saham periode t. Perhitungan Market return dan Company return dapat ditampilkan melalui rumus sebagai berikut: Market Return $=\left(\right.$ Harga $\mathrm{IHSG}_{\mathrm{t}}-\mathrm{Harga}$ $\left.\mathrm{IHSG}_{\mathrm{t}-1}\right) /$ Harga $\mathrm{IHSG}_{\mathrm{t}-1}$

Company Return $=\left(\right.$ Harga Saham S $_{\mathrm{t}}$ - Harga Saham $_{\mathrm{t}-1}$ ) / Harga Saham $\mathrm{t}-1$

5. Masa jabatan;

6. Perhitungan remunerasi direksi;

7. Fungsi dan kompetensi Direksi dan delegated management;

8. Daftar komite audit, remunerasi manajemen risik dan tata kelola perusahaan;

9. Nama akuntan publik;

10. Biaya audit dan biaya professional;

11. Pengungkapan laporan yang diterbitkan oleh bank investasi dan lembaga pemeringkat;

12. Pengungkapan masalah yang berhubungan rapat umum tahunan, agenda;

13. Pengungkapan sanksi yang dikenakan atau oleh perusahaan.

\section{Voluntary Corporate Governance Disclosure (VCGDI)}

Voluntary Corporate Governance

Disclosure dapat diukur dengan jumlah indeks pengungkapan informasi sukarela yang berkaitan dengan tata kelola perusahaan dibagi dengan total indeks pengungkapan sukarela yang berhubungan tata kelola perusahaan. Nilai pengungkapan meunjukan 1 apabila perusahaan ada mengungkapan informasi 
pada periode itu tersebut, jika tidak ada maka nilai pengungkapan adalah 0 . Total Voluntary

Corporate

Governance

Disclosure sebanyak 29 pengungkapan. Daftar Voluntary Corporate Governance Disclosure terdiri dari :

1. Opsi saham;

2. Pengungkapan anak perusahaan

3. Laba per saham dasar;

4. Laba per saham dilusi;

5. Kebijakan yang mengatur transaksi pihak berelasi;

6. Perhitungan remunerasi direksi;

7. Kewajiban imbalan kerja karyawan

8. Pengelolaan modal;

9. Regulatory framework management;

10. Anggaran dasar perusahaan;

11. Kelas saham;

12. Perubahan pemilik;

13. Rasio keuangan;

14. Perubahan susunan direksi;

15. Pengungkapan evaluasi kinerja perusahaan oleh direksi;

16. Pelatihan direksi;

17. Pengungkapan perkara atau masalah keuangan atau non keuangan;

18. Penunjukan kantor akuntan publik;

19. Penjelasan Alasan dibalik kebijakan akuntansi tertentu;

20. Konsistensi dengan standar akuntansi yang digunakan;

21. Norma-norma industri;

22. Informasi harga saham;

23. Laporan direksi;

24. Tinjauan operasional dan keuangan;

25. Fungsi internal kontrol pada internal audit;

26. Pengungkapan risiko keuangan dan risiko manajemen;

27. Pernyataan komitmen tata kelola perusahaan;

28. Lembaga penunjang profesi pasar modal;

29. Pengungkapan aktivitas tanggung jawab sosial atau CSR perusahaan. Sumber : ElKelish \& Hassan, (2015)

\section{Variabel Kontrol}

Variabel kontrol adalah variabel yang dibuat dengan konstan sehingga pengaruh variabel bebas terhadap variabel terikat tidak dapat dipengaruhi oleh faktor eksternal atau faktor luar. Variabel kontrol didalam penelitian ini terdiri dari kapitalisasi pasar (MCP), jumlah tahun periodeterdaftar di bursa efek (LST), profitabilitas (ROE), pertumbuhan penjualan (SLG), Tangibilitas (TAS), Laba dan Rugi (PL), Pembayaran Dividen (DIP), Persistensi Laba (EP), Magnitudes of Accrual 1 (MA1), Magnitudes of Accrual 2(MA2), Industri (IND).Berikut ini adalah pengukuran dari variabel kontrol:

\section{A. Kapitalisasi Pasar}

Log (kapitalisasi pasar) $=\log$ (jumlah saham beredar $\mathrm{x}$ harga saham saat penutupan)

B. Jumlah tahun terdaftar di Bursa Efek (LST)

LST $=$ Tahun periode yang berjalan Tahun Pendaftaran IPO

C. Profitabilitas (ROE)

ROE = laba bersih setelah pajak dibagi dengan total ekuitas

D. Rasio Tangibilitas (TAS)

TAS = Total Aset Tetap dibagi dengan Total Aset

E. Pertumbuhan Penjualan (SLG)

$\mathrm{SLG}=\left(\right.$ Penjualan $_{t}-$ Penjualan $_{\mathrm{t}}$ 1)/Penjualan ${ }_{\mathrm{t}-1}$

F. Laba dan Rugi (PL)

Penentuan laba dan rugi merupakan variabel dummy. Cara untuk mengukur variabel penentuan laba dan rugi adalah 1 jika perusahaan pada periode tersebut memiliki laba, dan 0 sebaliknya.

G. Pembayaran Dividen (DIP)

Pembayaran dividen diukur dengan variabel dummy. Jika perusahaan ada melakukan pembayaran dividen maka nilainya adalah 1 , dan 0 sebaliknya.

H. Persistensi Laba (EP)

$\mathrm{EP}=\alpha+\beta \mathrm{Laba}_{t}+\varepsilon$

I. Total Akrual (TAC) 
TAC $=$ Laba - Arus Kas dari aktivitas operasi

J. Manajemen Laba (MA2)

Magnitudes of Accrual 2 diadopsi dari perhitungan manajemen laba model jones pada tahun 1991 .

K. Industri

Pemilihan kategori industri merupakan variabel dummy. Jika perusahaan bergerak dibidang non keuangan maka menghasilkan nilai 0 . Sebaliknya, perusahaan yang bergerak dibidang keuangan akan mendapatkan nilai 1 .

\section{RESEARCH FINDINGS}

\section{Statistik Deskriptif}

Tabel 1

Hasil Uji Statistik Deskriptif-Skala Rasio

\begin{tabular}{cccccc}
\hline Variabel & N & Minimum & Maksimum & Mean & $\begin{array}{c}\text { Standar } \\
\text { Deviasi }\end{array}$ \\
& & & & & \\
\hline Share Price Accuracy & 1854 & $-2,399608$ & 0,456783 & $-0,911227$ & 0,542339 \\
MCGDI & 1854 & 0,538462 & 0,923077 & 0,735476 & 0,068093 \\
VCGDI & 1854 & 0,517241 & 0,896552 & 0,747765 & 0,068901 \\
Log (MCP) & 1854 & 8,477121 & 14,95164 & 12,19184 & 0,942868 \\
LST & 1854 & 1 & 67 & 16,58544 & 8,277099 \\
ROE & 1854 & $-178,1268$ & 10,30319 & $-0,018351$ & 4,202313 \\
TAS & 1854 & 0 & 2,625865 & 0,328047 & 0,27428 \\
SLG & 1854 & $-1,001938$ & 36,05109 & 0,214104 & 1,514835 \\
EP (Jutaan Rupiah) & 1854 & -22.400 .000 & 24.300 .000 & 534.000 & 2.160 .000 \\
MA1 (Jutaan Rupiah) & 1854 & -29.700 .000 & 29.300 .000 & 203.000 & 2.610 .000 \\
MA2 & 1854 & $-3,344031$ & 11,288300 & 0,001253 & 17,11505
\end{tabular}

Hasil analisis statistika deskriptif pada Tabel 1 menunjukan Share Price Accuracy sebagai variabel dependen memiliki nilai terendah sebanyak 2,399608. Nilai tertinggi Share Price Accuracy sebesar 0,456783. Nilai rata-rata sebesar -0,911227. Dan nilai standar deviasi sebesar 0,542339

Hasil statistika deskriptif pada Tabel 1 menampilkan Pengungkapan tata kelola perusahaan secara wajib yang diukur dengan MCGDI (Mandatory
Corporate Governance Disclosure Index) sebagai salah satu variabel independen. Nilai minimum pada MCGDI diperoleh oleh PT. Yulie Sekurindo Tbk sebesar 0,538462. Nilai maksimum pada MCGDI adalah sebesar 0,923077 .

Perusahaan yang memperoleh nilai maksimum pada MCGDI terdiri dari 12 perusahaan. Daftar 12 perusahaan yang memperoleh nilai indeks tertinggi yaitu PT. MNC Investama Tbk, Bank CIMB Niaga Tbk, Delta Dunia Makmur Tbk,

Program Studi Akuntansi, Fakultas Ekonomi, Universitas Internasional Batam | 56 
Jaya Real Property Tbk, Lippo Karawaci Tbk, Modernland Reality Tbk, Metropolitan Land Tbk, Plaza Indonesia Reality Tbk, Tambang Batubara Bukit Asam Tbk, Ristia Bintang Mahkota Sejati Tbk, Sampoerna Agro Tbk dan Surya Semesta Internusa Tbk. Nilai rata-rata dari MCGDI adalah sebesar 0,735476. Dan nilai standar deviasi pada MCGDI adalah sebesar 0,068093.

Hasil statistika deskriptif yang disajikan melalui Tabel 1 menunjukan Pengungkapan tata kelola perusahaan secara sukarela yang diukur dengan VCGDI (Voluntary Corporate Governance Disclosure Index). Nilai minimum pada VCGDI adalah sebesar 0,517241. Nilai terbesar pada VCGDI adalah sebanyak 0,896552 . Nilai rata-rata pada VCGDI adalah sebesar 0,735476. Dan nilai Standar Deviasi pada VCGDI adalah sebesar 0,068901.

Perusahaan yang memiliki nilai indeks yang terendah yaitu Prima Alloy Steel Universal Tbk. Sedangkan perusahaan yang memperoleh nilai indeks yang paling tinggi terdapat 21 perusahaan. 21 perusahaan tersebut yaitu Aneka Tambang Tbk, Agung Podomoro Land Tbk, Astra Graphia Tbk, Astra Internasional Tbk, Astra Autoparts Tbk, Bank Central Asia Tbk, Bank Bukopin Tbk, MNC Kapital Indonesia Tbk, Bank Mandiri Tbk, Bank CIMB Niaga Tbk, Bank Tabungan Pensiunan Nasional Tbk, Buana Listia Tama Tbk, Bukit Uluwatu Villa Tbk, Eagle High Plantation Tbk, HM Sampoerna Tbk, Indo Tambangraya Megah Tbk, Modernland Reality Tbk, Perusahaan Gas Negara (Persero) Tbk, United Tractors Tbk, Visi Media Asia Tbk, Wintermal Offshore Marine Tbk, dan Waskita Karya (Persero) Tbk. Perusahaan yang memperoleh nilai indeks yang rendah memiliki beberapa alasan seperti perusahaan tidak menerbitkan salah satu diantara laporan keuangan atau laporan tahunan dan perusahaan sudah di delisting oleh Bursa Efek Indonesia.
Hasil tampilan statistika deskriptif pada Tabel 1 menunjukan kapitalisasi pasar yang diukur dengan $\log (\mathrm{MCP})$ sebagai variabel kontrol. Nilai minimum pada $\log (\mathrm{MCP})$ adalah sebesar 8,477121. Nilai maksimum pada $\log (\mathrm{MCP})$ adalah 14,95164. Nilai mean pada $\log (\mathrm{MCP})$ adalah sebesar 12,19184. dan hasil standar deviasi pada $\log (\mathrm{MCP})$ adalah sebesar 0,942868 .

Hasil statistika deskriptif yang ditunjukan Tabel 1 menggambarkan jumlah tahun terdaftar di bursa efek yang diukur dengan LST sebagai variabel kontrol. Nilai minimum pada LST adalah sebesar 1 tahun. Nilai maksimum pada LST adalah sebanyak 67 tahun. Nilai ratarata pada LST adalah sebesar 16.58544. Sedangkan Nilai Srandar Deviasi pada LST adalah sebesar 8.277099.

Hasil analisis statistika deskriptif pada Tabel 1 membuktikan profitabilitas sebuah perusahaan yang dapat diukur dengan rumus ROE sebagai variabel kontrol. Nilai minimum pada ROE adalah sebesar -178,1268. Nilai maksimum pada ROE adalah sebesar 10,30319. Nilai ratarata pada ROE adalah sebesar $-0,018351$. Nilai standar deviasi pada ROE adalah sebesar 4,202313.

Hasil uji statistika deskriptif yang tertera pada Tabel 1 menunjukan rasio Tangibilitas yang diukur dengan TAS. Nilai minimum TAS adalah 0 . Nilai terbesar pada TAS adalah sebesar 1,135583. Nilai rata-rata pada TAS adalah sebesar 0,328047. Nilai standar deviasi pada TAS adalah sebesar 0,27428.

Hasil dari uji statistika deskriptif pada Tabel 1 menunjukan pertumbuhan penjualan yang diukur dengan SLG sebagai variabel kontrol. Hasil nilai minimum pada SLG adalah sebesar 1,001938. Nilai maksimum pada SLG adalah sebesar 36,05109 . Nilai mean pada SLG adalah sebesar 0,214104. Nilai standar deviasi pada SLG adalah sebesar 1,514835 .

Hasil dari statistika deskriptif persistensi laba pada Tabel 1 menunjukan 
nilai terkecil pada EP adalah sebesar $-22,4$ triliun. Nilai terbesar pada EP adalah sebesar 24,3 triliun. Nilai rata-rata pada EP adalah sebesar 534 miliar. Nilai standar deviasi pada EP adalah sebesar 2,16 triliun.

Hasil dari uji statistik deskriptif yang tertera di Tabel 1 menunjukan Magnitudes of Accrual 1(MA1) sebagai variabel kontrol. Nilai terkecil pada MA1 adalah sebesar minus 29.7 triliun. Nilai terbesar pada MA1 adalah sebesar 29.3 triliun. Nilai rata-rata pada MA1 adalah sebesar -203 miliar. Nilai pada standar deviasi MA1 adalah sebesar 2.61 triliun.

Hasil statistik deskriptif yang disampaikan melalui Tabel 1 menunjukan Magnitudes of Accrual 2 (MA2) sebagai variabel kontrol. Nilai minimum pada MA2 adalah sebesar -3,344031. Nilai maksimum pada MA2 adalah sebesar 11,288300. Nilai rata-rata pada MA2 adalah sebesar 0,001253. Nilai standar deviasi pada MA2 adalah sebsar 17,11505.

Tabel 2

Hasil Uji Statistik Deskriptif-Skala Nominal

\begin{tabular}{|c|c|c|c|}
\hline Variabel & Kategori & Frekuensi & Persentase \\
\hline \multirow[t]{2}{*}{ PL } & $\begin{array}{c}0=\text { Perusahaan menghasilkan Rugi } \\
\text { pada Tahun Berjalan }\end{array}$ & 369 & $19,9 \%$ \\
\hline & $\begin{array}{c}1=\text { Perusahaan menghasilkan Laba } \\
\text { pada Tahun Berjalan }\end{array}$ & 1485 & $80,1 \%$ \\
\hline \multirow[t]{2}{*}{ DIP } & $\begin{array}{c}0=\text { Perusahaan tidak membagikan } \\
\text { dividen }\end{array}$ & 1086 & $58,6 \%$ \\
\hline & 1 = Perusahaan membagikan & 768 & $41,4 \%$ \\
\hline \multirow[t]{2}{*}{ IND } & $\begin{array}{c}\text { dividen } \\
0=\text { Perusahaan bergerak di sektor }\end{array}$ & 1571 & $84,7 \%$ \\
\hline & $\begin{array}{c}\text { non keuangan } \\
1=\text { Perusahaan bergerak di sektor }\end{array}$ & 283 & $15,3 \%$ \\
\hline
\end{tabular}

Berdasarkan olahan data statistik deskriptif pada variabel PL, terdiri dari 2 kriteria yaitu nilai 0 bagi perusahaan yang menghasilkan rugi pada laporan laba rugi tahunan dan nilai 1 sebaliknya. Hasil uji menunjukan ada 369 data perusahaan yang masih mengalami kerugian atau tidak menghasilkan keuntungan pada tahun yang berjalan. Persentase pada perusahaan yang rugi yaitu sebesar 19,9\%. Sebaliknya, perusahaan yang menghasilkan laba pada tahun berjalan terdiri dari 1485 data. Jumlah persentase pada perusahaan yang menghasilkan laba yaitu sebesar $80,1 \%$.

Berikutnya dilanjutkan ke variabel pembayaran dividen yang disingkat sebagai DIP. Berdasarkan uji statistik deskriptif, terdapat 1086 data perusahaan yang memutuskan untuk tidak melakukan distribusi atau bagi dividen kepada investor dan pemegang saham. Persentase pada perusahaan publik yang tidak mau 
bagi dividen yaitu sebesar 58,6\%.. Dari 1086 data perusahaan tersebut yang tidak mau membagi dividen memiliki beberapa alasan seperti menutupi defisiensi modal, memperkuat struktur modal, perusahaan mengalami kerugian yang cukup besar, dan lain sebagainya. Sebaliknya, masih ada 768 data perusahaan yang membagi dividen kepada investor maupun pemegang saham dengan persentase $41,4 \%$.

Yang paling terakhir adalah variabel industri (IND). Berdasarkan tampilan pada Tabel 2 terdapat 1571 data yang bergerak di bidang non keuangan seperti pertanian, aneka industri, manufaktur dan masih banyak bidang usaha lainnya. Sedangkan perusahaan yang bergerak di bidang keuangan hanya terdapat 283 data saja. Persentase pada data perusahaan yang bergerak dibidang keuangan atau non keuangan yaitu sebesar $84,7 \%$ dan $15,3 \%$.

\section{Regresi Panel}

Tabel 3

Hasil Uji Chow

\begin{tabular}{|c|c|c|c|}
\hline Variabel & Effect Test & Prob. & Kesimpulan \\
\hline Share Price Accuracy & Cross Section-Chi-Square & 0,0000 & Fixed Effect Model \\
\hline \begin{tabular}{l}
\multicolumn{3}{c}{ Nilai probabilitas } \\
bisa diketahui melalui $\mathrm{Cr}$ \\
square. Hasil dari uji \\
merupakan tampilan $\mathrm{d}$
\end{tabular} & $\begin{array}{l}\text { pada uji chow } \\
\text { oss-section chi- } \\
\text { i chow yang } \\
\text { lari Tabel } 3\end{array}$ & $\begin{array}{r}\text { Tabel } 3 \\
\text { dari } 0 . \\
\text { baik ya } \\
\text { Fixed Eff }\end{array}$ & $\begin{array}{l}\text { niliki nilai yang kurang } \\
\text { Jadi sementara, model } \\
\text { dipakai untuk penelitian } \\
\text { Model. }\end{array}$ \\
\hline
\end{tabular}

menunjukan nilai probabilitas Crosssection chi-squarepada Uji chow adalah sebesar 0.0000. Artinya hasil probabilitas

Tabel 4

Hasil Uji Hasuman

\begin{tabular}{ccccc}
\hline Variabel & \multicolumn{2}{c}{ Effect Test } & Prob. & Kesimpulan \\
\hline Share Price Accuracy & \multicolumn{2}{c}{ Cross Section Random } & 1,0000 & Random Effect Model \\
\hline Hasil dari uji hausman yang & nilai lebih besar atau tinggi dari 0.05. \\
ditunjukan melalui Tabel & 4 mengartikan & Maka pemilihan model terbaik pada \\
bahwa tingkat probabilitas yang muncul & penelitian adalah Random Effect Model.
\end{tabular}

pada cross-section random uji hausman adalah sebesar 1.0000. Artinya hasil probabilitas pada Tabel 4 menghasilkan

Tabel 5

Hasil Uji F

\begin{tabular}{|c|c|}
\hline Variabel Dependen & Kesimpulan \\
\hline Share Price Accuracy & Signifikan \\
\hline $\begin{array}{l}\text { Uji F dilakukan untuk menguji } \\
\text { seberapa besar variabel independen } \\
\text { berpengaruh signifikan terhadap variabel } \\
\text { dependen bersamaan secara simultan. }\end{array}$ & $\begin{array}{l}\text { Hasil dari uji } \mathrm{F} \text { pada penelitian ini yaitu } \\
\text { sebesar } 0.0000 \text {. Hasil dari uji F } \\
\text { menunjukan bahwa semua variabel kontrol } \\
\text { dan independen yang ada didalam }\end{array}$ \\
\hline
\end{tabular}

Program Studi Akuntansi, Fakultas Ekonomi, Universitas Internasional Batam | 59 
penelitian dapat berpengaruh signifikan terhadap variabel dependen secara simultan.

Tabel 6

\begin{tabular}{cccccc} 
Hasil Uji T & \multicolumn{1}{c}{ Kesimpulan } & Hipotesis \\
\hline Variabel & Coefficient & t-Statistic & Prob. & & \\
\hline (Constant) & -0.910436 & & & & Terbukti \\
VCGDI & $6.63 \mathrm{E}-12$ & 11.75327 & 0.0000 & Signifikan & Terbukti \\
MCGDI & $-5.02 \mathrm{E}-12$ & -10.75839 & 0.0000 & Signifikan & \\
MCP & $-2.17 \mathrm{E}-12$ & -34.14545 & 0.0000 & Signifikan & \\
LST & $1.41 \mathrm{E}-12$ & 6.979955 & 0.0000 & Signifikan & \\
ROE & $-2.14 \mathrm{E}-15$ & -0.631441 & 0.5279 & Tidak Signifikan & \\
TAS & $-8.25 \mathrm{E}-14$ & -0.620593 & 0.5350 & Tidak Signifikan & \\
SLG & $2.79 \mathrm{E}-14$ & 2.959389 & 0.0031 & Signifikan & \\
PL & $8.92 \mathrm{E}-14$ & 1.801690 & 0.0718 & Tidak Signifikan & \\
DIP & $1.15 \mathrm{E}-13$ & 2.336097 & 0.0196 & Signifikan & \\
EP & $7.45 \mathrm{E}-26$ & 3.637630 & 0.0003 & Signifikan & \\
MA1 & $1.50 \mathrm{E}-27$ & 0.222605 & 0.8239 & Tidak Signifikan & \\
MA2 & $6.87 \mathrm{E}-14$ & 1.756802 & 0.0792 & Tidak Signifikan & \\
IND & $-6.47 \mathrm{E}-13$ & -2.111094 & 0.0349 & Signifikan &
\end{tabular}

Hasil dari Uji T Hasil dari Uji $\mathrm{T}$ menunjukan bahwa nilai probabilitas pada variabel MCGDI sebesar 0,0000. Artinya Mandatory Corporate Governance Disclosure pengaruh terhadap Share Price Accuracy secara signifikan karena hasil probabilitas pada variabel MCGDI lebih dari 0.05. Jadi kesimpulannya adalah menerima hipotesis 1 .

Mandatory Corporate Governance Disclosure pengaruh terhadap Share Price Accuracy karena pada umumnya pengungkapan wajib perusahaan publik di Indonesia telah diatur dalam peraturan BAPEPAM (Badan Pengawas Pasar Modal) nomor KEP 134-/BL/2006 dan OJK (Otoritas Jasa Keuangan). Pengungkapan wajib bersifat memaksa. Adanya pengungkapan wajib, dapat membuat suatu negara membuat strategi atau mempertegas peraturan pengungkapan wajib yang dapat berkontribusi untuk menciptakan pasar modal yang sehat dan optimal. Hasil dari penelitian ini konsisten dengan penelitian yang dilakukan oleh Fox, et al, (2003), ElKelish \& Hassan, (2015),
Hasil dari Uji T menunjukan bahwa nilai probabilitas pada variabel VCGDI sebesar 0.0000. Artinya Voluntary Corporate Governance Disclosure berpengaruh terhadap Share Price Accuracy secara signifikan karena hasil probabilitas pada variabel MCGDI kurang dari 0.05. Jadi kesimpulannya adalah Hipotesis 2 diterima.

Voluntary Corporate Governance Disclosure dapat berpengaruh terhadap Share Price Accuracy karena perusahaan mengungkapkan informasi keuangan atau non keuangan yang lebih bermanfaat untuk para traders. Informasi tersebut merupakan informasi yang diluar dari persyaratan regulator. Selain itu pengungkapan sukarela juga merupakan alat untuk meningkatkan kualitas tata kelola perusahaan. Pengungkapan informasi secara sukarela dapat memberikan referensi kepada investor untuk melakukan keputusan investasi dengan baik. Sehingga dana investasi dari investor ke perusahaan dapat dialokasi untuk menghasilkan laba dan harga saham yang akurat (Makeni, 2018). 
Tabel 7

Hasil Uji Koefisien Determinasi

\begin{tabular}{lcl}
\hline Variabel Dependen & R Square & \multicolumn{1}{c}{ Adjusted R Square } \\
\hline Share Price Accuracy & 1.00000 & 1.00000 \\
\hline \multicolumn{2}{c}{ Koefisien determinasi dilakukan } & $\begin{array}{l}\text { 1. Artinya pengaruh variabel independen } \\
\text { terhadap variabel dependen sebesar 100\% } \\
\text { tanpa adanya pengaruh faktor eksternal. }\end{array}$ \\
untuk mengetahui persentase kecocokan \\
model penelitian. Hasil dari koefisien
\end{tabular}

\section{CONCLUSION}

Penelitian ini menganalisis tentang Analisis Pengaruh Pengungkapan Tata Kelola Perusahaan terhadap Share Price Accuracy. Berdasarkan hasil uji analisis dan pembahasan sebelumnya, dapat ditarik beberapa kesimpulan bahwa kedua pengungkapan tata kelola perusahaan memiliki pengaruh yang signifikan terhadap akurasi harga saham.

Dalam penelitian ini, peneliti juga mendapatkan beberapa keterbatasan penelitian seperti penelitian akurasi harga saham yang sangat terbatas, pengungkapan tata kelola perusahaan yang masih tergolong subjektif, Literatur pendukung Mandatory Corporate Governance Disclosure dan Voluntary Corporate Governance Disclosure masih sangat terbatas. Dengan adanya keterbatasan, maka penulis sangat merekomendasikan kepada peneliti selanjutnya untuk mencoba variabel lain yang berpengaruh terhadap akurasi harga saham.

\section{REFERENCES}

Astuti, R., Lapian, J., \& Rate, P. Van. (2016). Pengaruh Faktor Makro Ekonomi Terhadap Indeks Harga Saham Gabungan (IHSG) di Bursa Efek Indonesia (BEI) Periode 20062015. Jurnal Berkala Ilmiah Efisiensi, 16(02), 399-406. https://doi.org/10.1126/science. 11517 51

Farvaque, E., Refait-Alexandre, C., \& Saïdane, D. (2011). Corporate disclosure: A review of its (direct and indirect) benefits and costs. Economie
Internationale, 128(4), 5-31. https://doi.org/10.1016/S21107017(13)60001-3

Fox, M. B., Durnev, A., Morck, R., \& Yeung, B. Y. (2003). Law, Share Price Accuracy and Economic Performance: The New Evidence. SSRN.

https://doi.org/10.2139/ssrn.437662

Haeberle, K. (2015). Stock Market Law and the Accuracy of Public Companies' Stock Prices, 121.

Jensen, M. C., \& Meckling, W. H. (1976). Theory of The Firm Manajerial Behaviour, Ageny Cost and Ownership structure. Journal of Financial Economics, 3, 305-360. Retrieved from http://uclafinance.typepad.com/main/f iles/jensen_76.pdf

Macey, J. R. (1993). Administrative agency obsolescence and interest group formation: A case study of the SEC at sixty. Cardozo L. Rev., 15, 909. Retrieved from http://heinonlinebackup.com/hol-cgibin/get_pdf.cgi?handle=hein.journals/ cdozo15\&amp;section $=45$

Makeni, E. N. (2018). the Effect of Foreign Direct Investments on Stock Market Returns At the Nairobi Securities Exchange By a Research Project Submitted in Partial Fulfillment of the Requirements for the Award of the Degree of Master of Science in Finance, School of Business, (December).

Morck, R., Yeung, B., Yu, W., Deardorff,

Program Studi Akuntansi, Fakultas Ekonomi, Universitas Internasional Batam | 61 
A., Fox, M., Froot, K., ... Yu, W. (2000). The Information Content of Stock Markets: Why Do Emerging Markets Have Synchronous Stock Price Movements? The Information Content of Stock Markets: Why Do Emerging Markets Have Synchronous Stock Price Movements ?

Odhiambo, J. (2000). DETERMINING THE ACCURACY OF THE NAIROBI STOCK EXCHANGE 20SHARE INDEX BY, (September).

Paramitasari, R. (2014). Analisis FaktorFaktor Yang Mempengaruhi Audit Delay Pada Perusahaan Lq45 Yang Terdaftar Di Bursa Efek Indonesia. Jurnal Akuntansi Dan Bisnis, 14(1), 129-140.

https://doi.org/10.20961/jab.v14i1.14 9

Romano, R. (1998). Empowering Investors: A Market Approach to Securities Regulation. Yale Law Journal, 107(8), 2359-2427.

Zamzany, F. R., Setiawan, E., \& Azizah, E. N. (2018). Reaksi Sinyal Keuangan Terhadap Harga Saham Sektor Pertanian di Indonesia. Esensi: Jurnal Bisnis Dan Manajemen, 8(2), 133140. https://doi.org/10.15408/ess.v8i2.759 8 